\title{
Threatened predator on the equator: multi-point abundance estimates of the tiger Panthera tigris in central Sumatra
}

\author{
Sunarto, Marcella J. Kelly, Sybille Klenzendorf, Michael R. Vaughan \\ Zulfahmi, M.B. Hutajulu and Karmila Parakkasi
}

\begin{abstract}
Information on spatial and temporal variation in abundance is crucial for effective management of wildlife. Yet abundance estimates for the Critically Endangered Sumatran tiger Panthera tigris sumatrae are lacking from Riau, the province historically believed to hold the largest percentage of this subspecies. Recently, this area has had one of the highest global rates of deforestation. Using camera traps we investigated tiger abundance across peatland, flat lowland, and hilly lowland forest types in the province, and over time, in the newly established Tesso Nilo National Park, central Sumatra. We estimated densities using spatially explicit capture-recapture, calculated with DENSITY, and traditional capture-recapture models, calculated with CAPTURE. With spatially explicit capture-recapture the lowest tiger density $(0.34 \pm$ SE 0.24 per $100 \mathrm{~km}^{2}$ ) was estimated in the hilly lowland forest of Rimbang Baling and the highest $\left(0.87 \pm\right.$ SE 0.33 per $\left.100 \mathrm{~km}^{2}\right)$ in the flat lowland forest of the Park. Repeated surveys in the Park documented densities of $0.63 \pm$ SE 0.28 in 2005 to $0.87 \pm$ SE 0.33 per $100 \mathrm{~km}^{2}$ in 2008 . Compared to traditional capture-recapture the spatially explicit capture-recapture approach resulted in estimates $50 \%$ lower. Estimates of tiger density from this study were lower than most previous estimates in other parts of Sumatra. High levels of human activity in the area appear to limit tigers. The results of this study, which covered areas and habitat types not previously surveyed, are important for overall population estimates across the island, provide insight into the response of carnivores to habitat loss, and are relevant to the interventions needed to save the tiger.
\end{abstract}

Keywords Camera trapping, density, human disturbance, Indonesia, Panthera tigris sumatrae, peatland, Riau, tiger

Sunarto* (Corresponding author), Marcella J. Kelly and Michael R. Vaughan Department of Fish \& Wildlife Conservation, Virginia Tech, 106 Cheatham Hall, Blacksburg, Virginia 24061-0321, USA

E-mail s.sunarto@yahoo.com

SyBiLLE KLENZENDORF WWF, Washington, DC, USA

Zulfahmi and Karmila PARAKKasi WWF-Indonesia, Jakarta, Indonesia

M.B. Hutajulu Balai Taman Nasional Tesso Nilo, Kab. Pelalawan, Riau, Indonesia

${ }^{*}$ Current address: WWF-Indonesia, Jakarta, Indonesia

Received 5 May 2011. Revision requested 6 July 2011.

Accepted 8 August 2011.

\section{Introduction}

O etermining population status is important for effective wildlife management (Krausman, 2002; Bolen \& Robinson, 2003). Additionally, knowledge of abundances and trends are required to determine the conservation status of a species (IUCN, 2001) and the actions needed to conserve populations (Nowell \& Jackson, 1996), and to evaluate the performance of conservation programmes. In addition, understanding the factors underpinning variation in abundance allows managers to identify conservation interventions.

Despite the critical status of the Sumatran tiger Panthera tigris sumatrae (Morell, 2007; Linkie et al., 2008b), the population status of this subspecies in the wild remains uncertain (Soehartono et al., 2007; Wibisono \& Pusparini, 2010). Although tiger density has been well documented in some areas, trends in population size across habitat types and over time remain poorly documented in Sumatra.

Historically, Riau Province was estimated to hold c. $30 \%$ of the Sumatran tiger population (Borner, 1978). Riau harbours not only hill and lowland forests, habitat types surveyed in previous studies in Sumatra, but also extensive peatland forests, which have never previously been surveyed for tigers. Although Riau Province has had an estimated deforestation rate of $65 \%$ over 25 years (Uryu et al., 2007) it still holds areas with high potential for tiger conservation and recovery (Sanderson et al., 2006; Walston et al., 2010; Wikramanayake et al., 2011).

We investigated tiger abundance across the various forest types in southern Riau Province and monitored changes in abundance over time in the newly established Tesso Nilo National Park. Our goals were to gain understanding of spatial and temporal variation in tiger density, to identify the factors that influence tiger numbers, and to explore management actions needed to conserve and restore tigers in the landscape.

\section{Study area}

This study was conducted in several forest blocks in southern Riau Province in central Sumatra (Fig. 1; Table 1; Sunarto, 2011). Systematic photographic sampling using camera traps was conducted in five blocks covering three forest types: the peat swamp forest of Kampar Peninsula and 


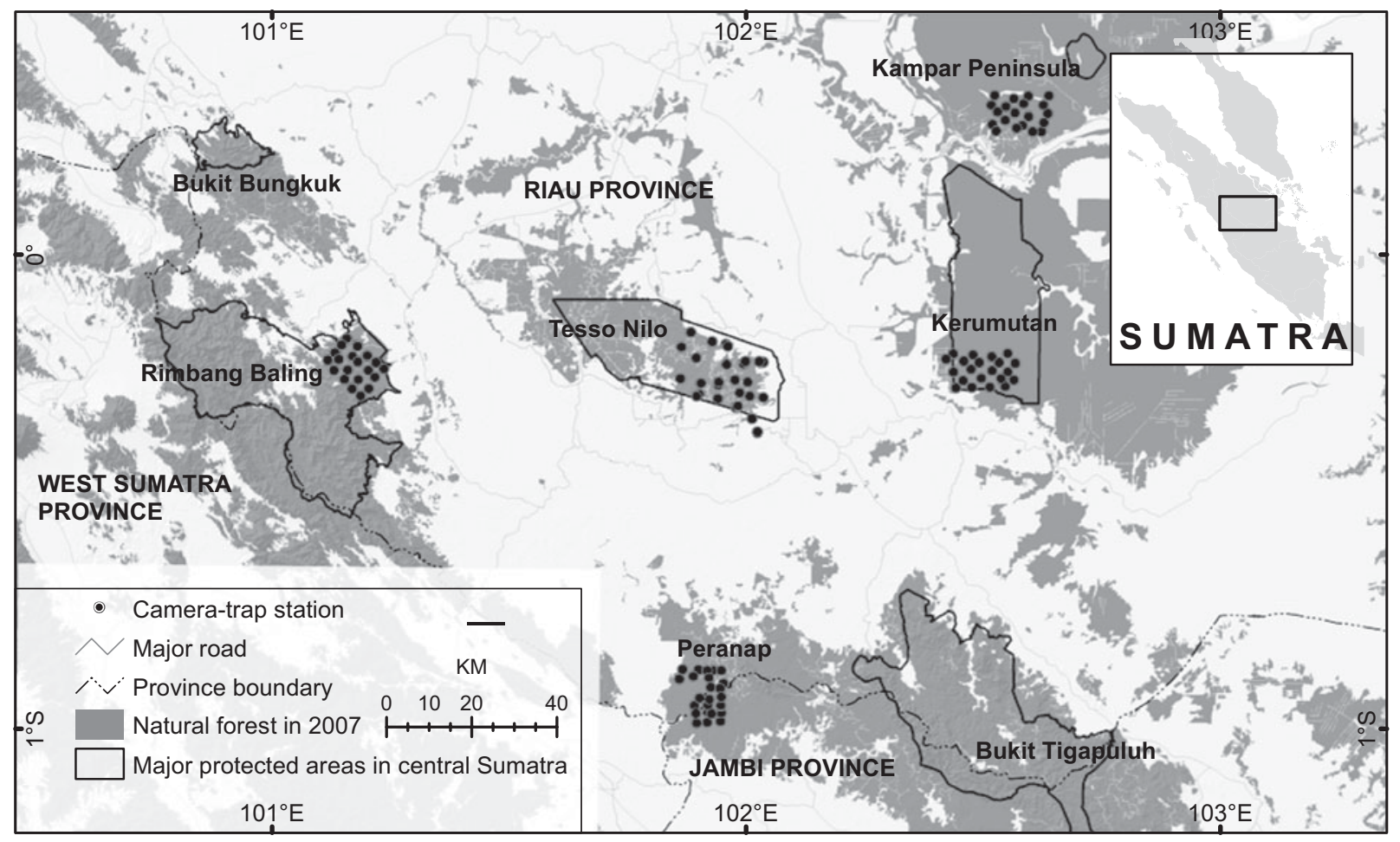

FIg. 1 The study area, showing forest cover in 2007, the five sampling blocks (Table 1) in Riau Province, central Sumatra, and the locations of camera traps. The rectangle on the inset indicates the location of the main map in central Sumatra.

TABLE 1 Characteristics of the five sampling blocks (Fig. 1) in southern Riau Province, central Sumatra.

\begin{tabular}{|c|c|c|c|c|c|}
\hline Characteristic & Kampar & Kerumutan & Tesso Nilo & Peranap & Rimbang Baling \\
\hline$\overline{\text { Altitude } \pm \text { SE (m) }}$ & $20 \pm 1.5$ & $33 \pm 1.8$ & $71 \pm 4.4$ & $132 \pm 4.2$ & $219 \pm 24.5$ \\
\hline Main soil type & Peat & Peat & Mineral & Mineral & Mineral \\
\hline Composite criteria $^{1}$ & Alluvial \& swamp & Alluvial \& swamp & Sedimentary & Sedimentary & Metamorphic \\
\hline $\begin{array}{l}\text { Protection status } \\
\text { (year established) }\end{array}$ & None & $\begin{array}{l}\text { Wildlife Reserve } \\
\text { (1979) }\end{array}$ & $\begin{array}{l}\text { National Park } \\
(2004)\end{array}$ & None & $\begin{array}{l}\text { Wildlife Reserve } \\
\text { (1982) }\end{array}$ \\
\hline Ex logging concession & Yes & No & Yes & Yes & Partly \\
\hline $\begin{array}{l}\text { Observed logging } \\
\text { impact }\end{array}$ & High & Low & Very high & Medium & Low \\
\hline Terrain & Flat & Flat & Generally flat & $\begin{array}{l}\text { Flat to gentle } \\
\text { hills }\end{array}$ & $\begin{array}{l}\text { Gentle to steep } \\
\text { hills }\end{array}$ \\
\hline Wetness & $\begin{array}{l}\text { Mostly inundated } \\
\text { in rainy season }\end{array}$ & $\begin{array}{l}\text { Mostly inundated } \\
\text { in rainy season }\end{array}$ & Mostly dry & Dry & Dry \\
\hline $\begin{array}{l}\text { Size of core forest block } \\
\left(\mathrm{km}^{2}\right)\end{array}$ & 3,060 & 3,790 & 860 & 1,860 & 1,680 \\
\hline
\end{tabular}

${ }^{1}$ From a combination of geological, bioclimatic, geomorphological and topographical maps, as identified by Laumonier (1997)

${ }^{2}$ Calculated by measuring forest area based on interpretation of Landsat images acquired in 2007 (by WWF Indonesia) corrected with $3-\mathrm{km}$ buffer, assuming an edge effect

Kerumutan (Plate 1), the flat lowland forest of Tesso Nilo and Peranap, and the hilly lowland forest of Rimbang Baling. Except in Kampar Peninsula and Peranap, the blocks are protected as either wildlife reserves (Kerumutan and Rimbang Baling) or as a National Park (Tesso Nilo). These forest blocks, interspersed with non-forested lands comprising mainly acacia and oil palm plantations, form a multi-use landscape covering a total area of c. $30,000 \mathrm{~km}^{2}$.

\section{Methods}

We estimated population densities of tigers using a capturerecapture approach, with standardized camera trapping procedures (Fig. 1), over 3 months for each sampling period to avoid violation of the closure assumption (Nichols \& Karanth, 2002). Each sampling block consisted of c. 40, $2 \times 2 \mathrm{~km}$ grid cells and we established at least 20 camera 


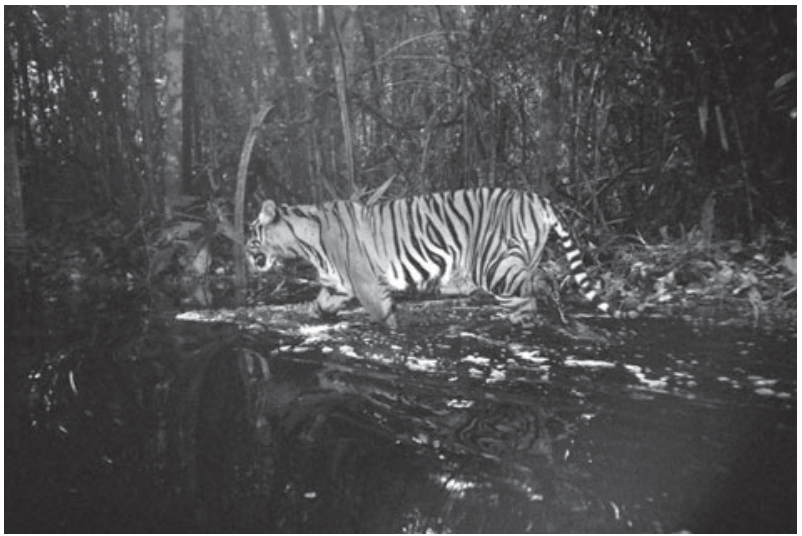

Plate 1 An adult female tiger photo-trapped in inundated peatland in Kerumutan (Fig. 1).

stations in each block, in every other grid cell. This spacing assured at least three pairs of cameras in each tiger's home range, assuming a home range size of c. $50 \mathrm{~km}^{2}$ in Sumatra (Franklin et al., 1999).

We placed cameras non-randomly (Karanth et al., 2002), based on characteristics such as suitable habitat and presence of tiger sign, within each pre-determined grid cell, to optimize captures of tigers whilst avoiding human disturbance/vandalism. At each site we installed a pair of opposing cameras c. $50 \mathrm{~cm}$ above the ground, at c. $2-3 \mathrm{~m}$ from the trail where animals were likely to pass. Individual tigers were distinguished by their unique stripe patterns (Karanth, 1995). The sampling period for each location is presented in Table 2.

\section{Density estimation}

We applied two approaches for estimating tiger density. Firstly, we used spatially explicit capture-recapture modelling within a maximum likelihood framework (Efford, 2004; Efford et al., 2004), implemented in DENSITY 4.4 (Efford, 2010). In the detection history one occasion represents a 24 -hour period of camera trapping. For every occasion we marked each camera station as active (1) when at least one camera was operational, or inactive (o) when no camera was working, and enabled incomplete trap layout in the input option of DENSITY. We used forest cover geographical information system layers from the same year of camera trapping (available from WWF; Uryu et al., 2007, 2010), and added a 4 -km buffer as the habitat mask. Tiger density was estimated using conditional likelihood with three detection functions (half-normal, hazard rate and negative exponential) assuming a Poisson distribution, all with a constant model for the intercept (i.e. the probability of capture when the trap and range centre coincide, $\left.g_{\mathrm{o}}[].\right)$ and spatial scale parameter $(\sigma[]$.$) . Covariates (such as response to capture)$ were not used because of the small sample sizes of captures and recaptures. We used the Akaike Information Criteria
(AIC; Akaike, 1973) for model selection, or that corrected for small sample size (AICc; Burnham \& Anderson, 1998).

Secondly, for comparison with other studies in Sumatra using the same approach, we used CAPTURE (Rexstad \& Burnham, 1992) to generate estimates of tiger abundance using K-sample closed population capture-recapture models (Nichols \& Karanth, 2002). As many zeros caused problems in the analysis with CAPTURE we collapsed every 10-day period into one sampling occasion. With a c. 3-month survey period this gave us 9-10 encounter occasions in the detection history. When the only competing model was $M_{\mathrm{O}}$ (model assuming equal capture probability for all animals) we used the heterogeneity model $\left(M_{\mathrm{h}}\right)$ with Jackknife estimator, which allows each individual to have different and unique detection probabilities (Otis et al., 1978) and is considered robust when heterogeneity is assumed to occur for territorial animals such as tigers (Nichols \& Karanth, 2002).

We calculated the density of tigers by dividing the abundance estimate by the area from which animals were sampled (Karanth \& Nichols, 1998). We estimated the area sampled as the polygon connecting the outermost cameras plus a buffer (the minimum convex polygon) of half the mean maximum distance moved ( $1 / 2 \mathrm{MMDM})$ by individuals captured at multiple stations (Karanth \& Nichols, 1998). We calculated variance in density using the delta method (Nichols \& Karanth, 2002). For sampling blocks that yielded too few recaptures of tigers at more than one location we borrowed recapture/movement distance data from the nearest blocks to calculate variance in density.

As an indicator of disturbance we assessed the level of human activity in each sampling block using the rate humans were photographed and level of vandalism to the cameras. Using $\chi^{2}$ goodness-of-fit statistics we tested between expected (null hypothesis of no difference) and observed numbers of independent photographs of the main tiger prey species among sites, habitat types and for Tesso Nilo National Park, among years of sampling. The expected numbers of independent photographs were calculated based on the proportion of effective trap nights for a given sampling block, forest type, or survey period. We defined photographs as independent following O'Brien et al. (2003). Statistical tests were performed in Excel 2007 (Microsoft, Redmond, USA) or $R$ v. 2.10.1 (R Development Core Team, 2008).

We defined effective trap nights as the number of nights multiplied by the number of camera stations minus any days where both cameras at a station malfunctioned. Paired cameras that operated for the same 24-hour period at the same station were considered one trap night. We calculated the photographic capture rates (O’Brien et al., 2003) by calculating the number of independent photographs per 100 trap nights. We focused on humans and the preferred prey of tigers: medium to large ungulates (the wild pig 


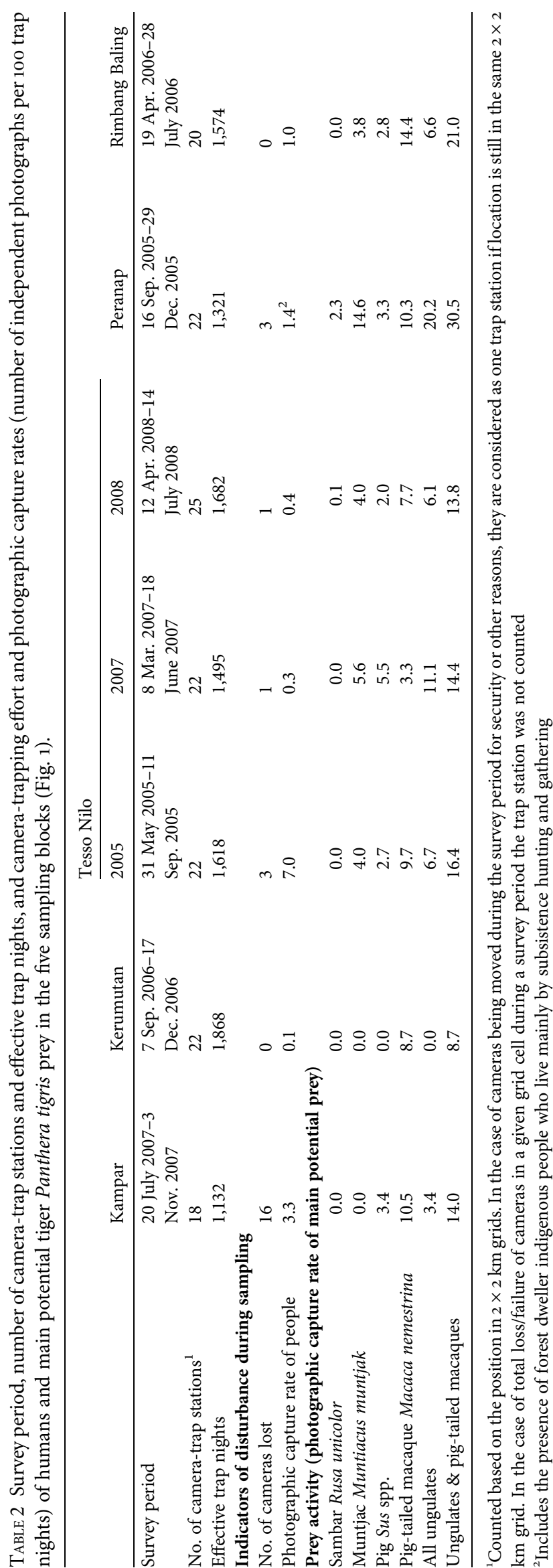

Sus scrofa, bearded pig Sus barbatus, muntjac Muntiacus muntjak, and sambar deer Rusa unicolor) and grounddwelling primates (the pig-tailed macaque Macaca nemestrina; Karanth \& Sunquist, 1995; Carbone et al., 1999; O'Brien et al., 2003; Sriyanto, 2003; Kawanishi \& Sunquist, 2004).

We compiled published information on tiger abundance in Sumatra for comparison with our results. We identified location, terrain, habitat type, year, tiger abundance and estimation method used. Where available, we extracted the 95\% confidence limits of the abundance estimate. If the confidence limits were not available we determined plausible lower and upper bounds given the description in the original text.

\section{Results}

From 10,690 effective trap nights we obtained a total of 174 photographs of tigers (Plate 1; Tables $2 \& 3$ ) from which we identified 18 individual tigers. Effective trap nights ranged from 1,132 (Kampar) to 1,868 (Kerumutan), and the number of active stations ranged from 18 (Kampar) to 25 (Tesso Nilo National Park). Overall, we obtained most samples, both the number of tiger photographs and number of unique individuals, from Tesso Nilo National Park. The number of individual tigers identified from Tesso Nilo in 2005, 2007 and 2008 was five, seven and six, respectively. Except for two tigers that were captured (and recaptured) in all three sampling years in the Park, other individuals were unique to each survey period.

Despite the presence of tiger sign in every sampling block we failed to photograph tigers in Kampar and Peranap during the systematic camera trapping. In these two blocks camera operations were disrupted by vandalism or theft of 16 cameras in Kampar and three in Peranap. In addition to losing camera units, we also documented relatively high human activity (Table 2).

\section{Density estimates}

Density estimates using the best spatially explicit capturerecapture models range from 0.34 individuals per $100 \mathrm{~km}^{2}$ in Rimbang Baling in 2006 to 0.87 per $100 \mathrm{~km}^{2}$ in Tesso Nilo in 2007 (Table $3 \& 4$ ). Tiger density in Tesso Nilo National Park from three different year samples estimated using spatially explicit capture-recapture remained relatively constant with no obvious trend. Estimates of tiger density in Kerumutan and Rimbang Baling were lower than those for any survey period in Tesso Nilo.

Estimates using spatially explicit capture-recapture models were consistently and substantially lower than those from traditional capture-recapture models. In CAPTURE abundance was estimated using model $M_{\mathrm{h}}$ in 
TABLE 3 Summary of the estimates of tiger density (individuals per $100 \mathrm{~km}^{2}$ ) in the five sampling blocks (Fig. 1).

\begin{tabular}{|c|c|c|c|c|c|c|c|}
\hline & \multirow[b]{2}{*}{ Kampar } & \multirow[b]{2}{*}{ Kerumutan } & \multicolumn{3}{|l|}{ Tesso Nilo } & \multirow[b]{2}{*}{ Peranap } & \multirow{2}{*}{$\begin{array}{l}\text { Rimbang } \\
\text { Baling }\end{array}$} \\
\hline & & & 2005 & 2007 & 2008 & & \\
\hline $\begin{array}{l}\text { No. of independent tiger } \\
\text { photographs }\end{array}$ & $0^{1}$ & 14 & 38 & 40 & 75 & $0^{1}$ & 7 \\
\hline Tiger photographic capture rate ${ }^{2}$ & & 0.7 & 2.3 & 2.7 & 4.5 & & 0.4 \\
\hline No. of individual tigers & $0^{1}$ & 2 & 5 & 7 & 6 & $0^{1}$ & 2 \\
\hline Area effectively sampled ${ }^{3}\left(\mathrm{~km}^{2}\right)$ & 559 & 582 & 779 & 617 & 470 & 431 & 354 \\
\hline $\mathrm{MMDM}^{4} \pm \mathrm{SD}$ & & 14.36 & $11.37 \pm 5.92$ & $11.65 \pm 8.94$ & $7.31 \pm 3.97$ & & 9.79 \\
\hline Selection criteria under Model $M_{\mathrm{h}}$ & & 0.92 & 0.87 & 0.95 & 0.93 & & 0.85 \\
\hline Closure test $z$ value $(\mathrm{P})$ & & $-0.99(0.16)$ & $-1.75(0.04)$ & $-0.36(0.36)$ & $-0.89(0.18)$ & & $-0.30(0.38)$ \\
\hline Probability of capture $(\hat{P})^{5}$ & & 0.167 & 0.243 & 0.243 & 0.263 & & 0.100 \\
\hline$\hat{N}^{6} \pm \mathrm{SE}$ & & $3 \pm 1.38)$ & $7 \pm 2.57)$ & $7 \pm 2.47)$ & $8 \pm 2.80)$ & & $3 \pm 1.36$ \\
\hline$\hat{D}^{7} \pm \mathrm{SE}$ & & $0.52 \pm 0.27^{8}$ & $0.89 \pm 0.38$ & $1.13 \pm 0.58$ & $1.70 \pm 0.66$ & & $0.86 \pm 0.50$ \\
\hline
\end{tabular}

${ }^{1}$ Tigers confirmed to be present based on their sign (pug-mark and/or scat)

${ }^{2}$ Number of independent photographs per 100 trap nights

${ }^{3}$ Calculated based on minimum convex polygon of outer camera points buffered with $1 / 2 M M D M$; for sampling blocks without tiger photographic captures,

$1 / 2 \mathrm{MMDM}$ was borrowed from the nearest block

${ }^{4}$ Mean maximum distance moved $(\mathrm{km})$

${ }^{5}$ Based on capture history, with one occasion representing 10 trap days

${ }^{6}$ Estimated total number of individuals in the sampling block

${ }^{7}$ Estimated density (individuals per $100 \mathrm{~km}^{2}$ )

${ }^{8}$ Because of the limited number of individuals photographed density was calculated by borrowing data on tiger distance moved from the neighbouring sampling blocks

TABLE 4 Model selection (ranked for each survey session based on AIC) and estimates of tiger density (individuals per $100 \mathrm{~km}^{2}$ ) for Kerumutan (in 2006), Tesso Nilo (in 2005, 2007, 2008) and Rimbang Baling (in 2006) based on spatially explicit capture-recapture models with conditional maximum likelihood estimators in DENSITY.

\begin{tabular}{|c|c|c|c|c|c|c|c|c|}
\hline Detection function $^{1}$ & K & $\mathrm{AIC}^{2}$ & $\mathrm{AICc}^{3}$ & $\Delta \mathrm{AICc}$ & $w_{\mathrm{i}}^{4}$ & $\hat{D}^{5} \pm \mathrm{SE}$ & $g_{0}^{6} \pm \mathrm{SE}$ & $\sigma^{7} \pm S E$ \\
\hline \multicolumn{9}{|c|}{ Kerumutan, $2006($ captures $=6$, individuals $=2$, recaptures $=4)$} \\
\hline Hazard rate & 3 & 89.04 & & 0 & 0.5 & $0.41 \pm 0.29$ & $0.035 \pm 0.036$ & $1,262.5 \pm 1,172.7$ \\
\hline Negative exponential & 2 & 89.46 & & 0.42 & 0.4 & $0.34 \pm 0.24$ & $0.019 \pm 0.016$ & $2,797.7 \pm 1,534.9$ \\
\hline Half normal & 2 & 90.86 & & 1.82 & 0.2 & $0.25 \pm 0.18$ & $0.006 \pm 0.005$ & $6,025.6 \pm 2,217.6$ \\
\hline \multicolumn{9}{|c|}{ Tesso Nilo, 2005 (captures $=27$, individuals $=5$, recaptures $=22)$} \\
\hline Negative exponential & 2 & 321.73 & 327.73 & 0 & 0.9 & $0.63 \pm 0.28$ & $0.060 \pm 0.025$ & $2,227.6 \pm 475.9$ \\
\hline Half normal & 2 & 326.59 & 332.59 & 4.86 & 0.1 & $0.59 \pm 0.26$ & $0.020 \pm 0.006$ & $4,006.8 \pm 656.3$ \\
\hline Hazard rate & 3 & 321.79 & 345.79 & 18.06 & 0.0 & $0.59 \pm 0.26$ & $0.049 \pm 0.026$ & $2,115.1 \pm 790.3$ \\
\hline \multicolumn{9}{|c|}{ Tesso Nilo, 2007 (captures $=26$, individuals $=7$, recaptures $=19)$} \\
\hline Half normal & 2 & 317.07 & 320.07 & 0 & 1.0 & $0.87 \pm 0.33$ & $0.020 \pm 0.010$ & $5,082.5 \pm 815.6$ \\
\hline Hazard rate & 3 & 321.38 & 329.38 & 9.31 & 0.0 & $0.84 \pm 0.32$ & $0.006 \pm 0.000$ & $12,200 \pm 271.4$ \\
\hline Negative exponential & 2 & 341.49 & 344.49 & 24.42 & 0.0 & $0.72 \pm 0.27$ & $0.002 \pm 0.000$ & \\
\hline \multicolumn{9}{|c|}{ Tesso Nilo, 2008 (captures $=44$, individuals $=6$, recaptures $=38)$} \\
\hline Hazard rate & 3 & 441.53 & 453.53 & 0 & 0.7 & $0.8 \pm 0.33$ & $0.031 \pm 0.006$ & $8,197.8 \pm 263.4$ \\
\hline Half normal & 2 & 451.35 & 455.35 & 1.82 & 0.3 & $0.77 \pm 0.32$ & $0.063 \pm 0.01$ & $3,907.7 \pm 399.2$ \\
\hline Negative exponential & 2 & 456.09 & 460.09 & 6.56 & 0.0 & $0.76 \pm 0.31$ & $0.210 \pm 0.120$ & $2,212.3 \pm 333.4$ \\
\hline \multicolumn{9}{|c|}{ Rimbang Baling, 2006 (captures $=5$, individuals $=2$, recaptures $=3$ ) } \\
\hline Half normal & 2 & 74.19 & & 0 & 0.4 & $0.34 \pm 0.24$ & $0.006 \pm 0.005$ & $5,630.7 \pm 4936.8$ \\
\hline Negative exponential & 2 & 74.26 & & 0.07 & 0.4 & $0.36 \pm 0.25$ & $0.012 \pm 0.015$ & $3,716.9 \pm 5645.2$ \\
\hline Hazard rate & 3 & 75.72 & & 1.53 & 0.2 & $0.35 \pm 0.25$ & $0.004 \pm 0.003$ & $10,093.0 \pm 332.1$ \\
\hline
\end{tabular}

${ }^{1}$ All models used did not consider covariates $\left(g_{0}[] s.[].\right)$; length of buffer used was 10,000 m

${ }^{2} \mathrm{AIC}$, Akaike Information Criteria

${ }^{3} \mathrm{AICc}$, AIC corrected for small sample size

${ }^{4} W_{\mathrm{i}}$, Akaike weights (the probability that the given model is the best model. The value ranges from o to 1 .)

${ }^{5} \hat{D}$, estimated density (individuals per $100 \mathrm{~km}^{2}$ )

${ }^{6} \mathrm{~g}_{0}$, intercept (the probability of capture when the trap and range centre coincide)

${ }^{7} \sigma=$ sigma (a spatial scale parameter) 
all cases (Table 3). Closure tests indicated that the data did not violate the closure assumption at any site $(\mathrm{P}>0.15)$, except in one survey in Tesso Nilo in $2005(\mathrm{P}=0.04)$. With traditional capture-recapture models estimates of tiger density were $1.2 \pm \mathrm{SE} 0.54$ individuals per $100 \mathrm{~km}^{2}$ in flat lowland forest of Tesso Nilo, $0.5 \pm$ SE 0.27 per $100 \mathrm{~km}^{2}$ in peatland forest of Kerumutan, and $0.9 \pm$ SE 0.43 per $100 \mathrm{~km}^{2}$ in hilly lowland forest of Rimbang Baling.

Although point estimates of tiger density varied, no estimate was found to be significantly different from any others because of their large confidence intervals. For Kampar and Peranap, where we did not photograph tigers but observed their sign, we assumed tiger density was lower than the site with the lowest density estimate (Kerumutan).

\section{Human activity}

Despite mitigation measures there was considerable vandalism of the camera stations and we lost 24 camera units during the systematic sampling. Only in Kerumutan and Rimbang Baling was there no trap loss. We documented high human activities in Kampar, Peranap and Tesso Nilo (Table 2).

\section{Photographic capture rates of potential prey}

Photographic capture rates of prey, by species or prey groups, was significantly different among sites (all $\chi^{2}>61$, $\mathrm{df}=4$, all $\mathrm{P}<0.01$ ) and among forest types (all $\chi^{2}>20$, $\mathrm{df}=2$, all $\mathrm{P}<0.01$; Table 2). Within Tesso Nilo National Park we found a significant difference among years only for muntjac $\left(\chi^{2}=5.9, \mathrm{df}=2, \mathrm{P}=0.05\right)$ and no significance for the combination of three ungulate species (wild pig, muntjak, and sambar; $\chi^{2}=4.23, \mathrm{df}=2, \mathrm{P}=0.12$ ), whereas other species and combinations of ungulates and pig-tailed macaque varied significantly across the years (all $\chi^{2}>13$, $\mathrm{df}=2$, all $\mathrm{P}<0.01$.

Some species of ungulates were apparently absent from some areas. Sambar, for example, were photographed in only two sites, and in one of those sites captures were low, considering the effort. No sambar and zero, or extremely low numbers, of other ungulates were photographed in peatland forest (Table 2).

\section{Comparison with tiger abundances in other areas}

We found substantially lower tiger densities compared to studies elsewhere in Sumatra, which have ranged from $1.5^{-2.1}$ individuals per $100 \mathrm{~km}^{2}$ in submontane primary forest to 3.3 per $100 \mathrm{~km}^{2}$ in lowland primary forest (Table 5).

\section{Discussion}

This study is the first in Sumatra to investigate trends in tiger population across habitat types and over time, and the first to provide information on tiger abundance in Riau Province and in peatland areas. It is also the first study estimating the population of Sumatran tigers using spatially explicit capture-recapture models, and provides an insight into the ecology of a threatened large carnivore living in a landscape under intense pressure.

Although point estimates for tiger density in central Sumatra appear to vary by habitat, sampling block, and through time in the same area, our results had low precision. Our low sample sizes (i.e. the number of individuals photographed) were not because of lack of effort as our study had equal or larger numbers of trap nights and area sampled compared to other studies. For example, in India, Karanth et al. (2006) photographed 74 individual tigers in a total of 5,725 total trap nights and took a mean of 7.73 trap nights to photograph one individual, whereas we photographed 18 individuals in 10,690 trap nights and took an average of 590 trap nights to photograph an individual.

Compared to other studies using similar techniques our estimates of tiger densities in Sumatra are lower than expected, often $<_{1}$ tiger per $100 \mathrm{~km}^{2}$, even compared to similar habitat elsewhere (Karanth \& Nichols, 1998; Kawanishi \& Sunquist, 2004; Karanth et al., 2006; Linkie et al., 2006; Rayan \& Mohamad, 2009; Table 5). Using spatially explicit capture-recapture models our estimates of tiger density were almost $50 \%$ lower compared to densities estimated with traditional capture-recapture models, a finding noted in other studies (Tredick \& Vaughan, 2009; Obbard et al., 2010; Sharma et al., 2010; Gerber et al., 2012).

\section{Prey availability}

Prey availability has been identified as the single most important factor influencing tiger abundance (Karanth et al., 2004), and depletion of prey significantly affects tiger population viability (Karanth \& Smith, 1999). We found that photographic capture rate of prey per se was not a predictor of tiger density. For example, Peranap had a very low tiger density but the highest level of photographic capture rate of prey and the most diverse prey assemblage. Potential prey in this area included sambar, which were not detected in most of the other sites and is the preferred prey of tigers (Carbone \& Gittleman, 2002).

Although we did not detect tigers by cameras in Peranap we found tiger pug-marks during camera placement. We believe that the low detection of tigers in this area was a result of the high level of human activity, including farming, hunting/trapping, and gathering of forest products by villagers, migrants or nomadic indigenous communities. Riau Province is known to be a major transit area for the illegal wildlife trade ( $\mathrm{Ng} \&$ Nemora, 2007) and one of the main sources of tiger body parts (Osmantri/WWF anti-poaching 
TABLE 5 Estimates of tiger density in various locations in Sumatra and, for comparison, the results from this study in the five sampling blocks in central Sumatra (in bold).

\begin{tabular}{|c|c|c|c|c|c|c|c|}
\hline \multirow[b]{2}{*}{ Site $^{1}$} & \multirow[b]{2}{*}{ Terrain } & \multirow[b]{2}{*}{ Forest type } & \multirow[b]{2}{*}{ Protection status } & \multicolumn{3}{|c|}{ Density (individuals per $100 \mathrm{~km}^{2}$ ) } & \multirow[b]{2}{*}{ Year } \\
\hline & & & & Median/mean & Lower & Upper & \\
\hline Leuser $^{2}$ & Hill & Primary & National Park & 1.3 & 1.0 & 1.6 & 1992 \\
\hline Way Kambas ${ }^{3}$ & Flat lowland & Secondary & National Park & 2.9 & 1.6 & 4.3 & 1995-1997 \\
\hline $\mathrm{Jambi}^{4}$ & Flat lowland & Secondary & None & 13.5 & 10 & 17 & 2001-2001 \\
\hline Burkit Barisan Selatan ${ }^{\star 5}$ & Lowland hill & Primary & National Park & 1.6 & 1.2 & 3.2 & 1998-1999 \\
\hline Kerinci Seblat ${ }^{* 6}$ & Lowland hill & Primary & National Park & 3.3 & 3.3 & 9.9 & 2001-2002 \\
\hline Kerinci Seblat ${ }^{{ }^{6}}$ & Hill & Primary & National Park & 2.0 & 2.0 & 4.1 & 2001-2002 \\
\hline Kerinci Seblat ${ }^{\star 6}$ & Submontane & Primary & National Park & 1.5 & 1.5 & 4.0 & 2001-2002 \\
\hline Kerinci Seblat $^{6}$ & Montane & Primary & National Park & 0.3 & 0.1 & 1.4 & 2001-2002 \\
\hline Batang Gadis ${ }^{{ }^{7}}$ & Hill & Primary & National Park & 1.8 & 1.8 & 6.4 & 2005-2006 \\
\hline Kerinci Seblat (Bungo) ${ }^{\star 8}$ & Hill & Secondary & None & 3.0 & 2.5 & 5.0 & 2007 \\
\hline Kerinci Seblat (Ipuh) $)^{\star 8}$ & Hill & Secondary & None & 1.55 & 1.3 & 2.9 & 2007 \\
\hline Kampar $^{9}$ & Peatland & Secondary & None & $<0.5$ & & & 2007 \\
\hline Kerumutan* & Peatland & Primary & Wildlife Reserve & 0.5 & $\mathbf{0}$ & 1.0 & 2006 \\
\hline Tesso Nilo ${ }^{\star 10}$ & Flat lowland & Secondary & National Park & 1.2 & 0.2 & 2.3 & 2005-2008 \\
\hline Peranap $^{9}$ & Flat lowland & Secondary & None & $<0.5$ & & & 2005 \\
\hline Rimbang Baling ${ }^{\star}$ & Lowland hill & Primary & Wildlife Reserve & 0.9 & $\mathbf{0}$ & 1.7 & 2006 \\
\hline
\end{tabular}

${ }^{1}$ An asterisk indicates use of the standardized traditional capture-recapture approach (Karanth \& Nichols, 2002) to estimate tiger density

${ }^{2}$ Estimate in Gunung Leuser was based on a combination of the total number of camera-trap photographs and extrapolation with a geographical information system, with density derived from estimates of the total population divided by total area (Griffiths, 1994)

${ }^{3}$ Value presented is the median between the low and high estimates. Density in Way Kambas was estimated based on total number of resident individuals photographed over 16 months of sampling and additional projected monthly mean of non-resident individuals (Franklin et al., 1999).

${ }^{4}$ Maddox et al. (2007) estimated the density based on photographic capture rate using the conversion factor presented by Carbone et al. (2001)

${ }^{5}$ Estimates were made based on traditional capture-recapture models with individuals identified based on pelage patterns on the left flank (O'Brien et al., 2003) ${ }^{6}$ Estimate for montane forest was based on encounter rate (Linkie et al., 2006)

${ }^{7}$ Wibisono et al. (2009) ${ }^{8}$ Linkie et al. (2008a)

${ }^{9}$ Although confirmed to be present, tigers were not photographed in camera traps during systematic camera-trap sampling. Density is, therefore, assumed to be lower than the site with the lowest density (Kerumutan)

${ }^{10}$ Mean values from three consecutive estimates using traditional capture-recapture models (Table 3 )

team leader, pers. comm.; Shepherd \& Magnus, 2004). Notorious hunters, including one local person who claimed to have killed more than 50 tigers (Abi, 2010), formerly lived and operated in the Province. Unprotected areas such as Peranap can easily become the target for poachers.

The failure to detect tigers in Kampar is probably because of a combination of low prey availability and the high level of human activity. Prey populations are low in peatland forests, perhaps related to low primary productivity and a high level of plant defence mechanisms, discouraging herbivory (Whitten et al., 2000). The loose and porous texture of peat makes movement difficult, especially for ungulates with their relatively high body mass and pointed hooves. Additionally, many of these areas are inundated during the rainy season, making movement and feeding difficult in that period. With the ability to climb trees when needed to move and forage, pig-tailed macaques thrive in these areas, and are the main prey available for tigers.

\section{Determinants of tiger abundance}

The low capture rates and estimated densities of tigers documented in this study are most likely related to a combination of habitat quality, prey availability and human activity. High levels of human activity were expected because, during the last decade, Riau had the highest human population growth (c. 4\%) in Indonesia (BAPPENAS, 2005). During their operation from 2007 to early 2010, WWF and the Forestry Department antipoaching team detected and confiscated 87 metal snares typically used for tigers and 265 nylon snares used for other animals (Osmantri/WWF anti-poaching team leader, pers. comm.).

We experienced no camera loss in Kerumutan and Rimbang Baling. These are the only blocks in our survey that have been legally protected for 3 decades or longer, suggesting that long-term legal protection is recognized by local people and migrants, discouraging them from trespassing.

In northern Sumatra Griffiths \& van Schaik (1993) documented significantly reduced activities of tigers and other wildlife species in areas with higher levels of human activity. We documented a decline in human activity over time and a stable tiger density in Tesso Nilo National Park in the same period. Our observations in the field suggested that in 2008 people appeared to halt activities following the 
establishment and active management of the National Park. A similar result was documented in Rajaji National Park, India, where tiger density increased following the removal of anthropogenic influences (Harihar et al., 2009), showing that strong protection can be effective in maintaining a high density of tigers (Karanth \& Nichols, 1998; Karanth et al., 2004; Ahmed et al., 2010).

\section{Management implications and conclusion}

The conservation community plans to double or significantly increase the global tiger population in the next decade (Global Tiger Recovery Program, 2010). This vision seems overly optimistic considering the widespread deforestation that is still taking place in many areas, including central Sumatra. It is possible, however, to increase tiger density if limiting factors can be removed. In central Sumatra the most important factor to control is the high level of illegal human activity. Legal protection of an area, followed by strong protection and intensive management can reduce the level of human disturbance and facilitate the recovery of the habitat and prey, and thus tigers.

Opportunities to protect legally or intensify management of tiger habitats are still available in Riau. For example, the majority of the Kampar Peninsula, a large portion of the Kerumutan block to the east, the Peranap forest area, and forests around Rimbang Baling Wildlife Reserve currently have little to no protection. Without action these areas may soon lose their forest because of ubiquitous and rampant conversion of forests to plantations.

Traditional protection such as that afforded by national parks and wildlife reserves has proven effective in reducing deforestation in some areas (Gaveau et al., 2009) but there are other alternatives to improve tiger habitat whilst promoting local and national economic development, such as through agroforestry or selective and sustainable logging. Conversion of forest into acacia and oil palm plantations is driven by the global demand for these products. Therefore, the international community needs to share the responsibility and join with national and local communities to take a range of measures to conserve the tiger.

Tigers appear to live at much lower densities in central Sumatra than documented elsewhere. This strongly indicates that tigers may not do well in some areas even when the forest is seemingly intact. More intensive monitoring and proactive management of tiger populations and their habitats are needed if we are to avoid local tiger extinctions. Our findings suggest that the high level of human activity is one key limiting factor preventing tigers from attaining higher density. Although our study generally presents a somewhat bleak picture for the tiger in central Sumatra, we documented a potentially stable tiger population in Tesso
Nilo National Park during this study, where legal protection is discouraging destructive human activities and allowing the tiger and its prey to recover.

\section{Acknowledgements}

WWF Indonesia and Networks, the Hurvis Family, the Critical Ecosystem Partnership Fund, the National Fish and Wildlife Foundation/Save the Tiger Fund, USFWS Rhino Tiger Conservation Fund, and Virginia Tech provided technical and financial support for this study. We thank the Indonesian Ministry of Forestry, specifically the Director of Biodiversity Conservation and the managers and staff of the protected areas (especially those from BBKSDA Riau and Balai Taman Nasional Tesso Nilo) for supporting this study. Jim Nichols provided guidance in study design and useful input. This study relied on the support of the WWF team and many field technicians and volunteers, including $\mathrm{H}$. Kurniawan, E. Septayuda, Kusdianto, F. Panjaitan, A. Suprianto, E. Tugiyo, L. Subali and H. Gebog. Koko Yulianto assisted with geographical information systems and mapping. Hariyo T. Wibisono, T. Maddox and J. Sanderson shared their approach to organizing camera trap data. J.E. Hines and Brian Gerber helped with analytical procedures. R. Sugiyanti, Mark Rayan D. and two anonymous reviewers provided useful comments.

\section{References}

ABI (2010) Kakek 92 tahun bunuh 50 harimau. Kompas, 20 March 2010. Gramedia, Jakarta, Indonesia.

Ahmed, M.F., Borah, J., Das, C., Basumatary, A., Sarma, R.N., Gogor, D.D. et al. (2010) Monitoring Tigers and Prey Animals of Kaziranga National Park, Assam, India. Assam Forest Department \& Aaranyak, Guwahati, India.

Акалке, H. (1973) Information theory and an extension of the maximum likelihood principle. In Second International Symposium on Information Theory (eds B.N. Petrov \& B.F. Csaki), pp. 267-281. Akademiai Kiado, Budapest, Hungary.

BAPPENAS (2005) Proyeksi Penduduk Indonesia (Indonesia population projection) 2000-2025. Badan Perencanaan Pembangunan Nasional, Badan Pusat Statistik, UN Population Fund, Jakarta, Indonesia.

Bolen, E.G. \& Robinson, W.L. (2003) Wildlife Ecology and Management, 5 th edition. Prentice Hall, New Jersey, USA.

Borner, M. (1978) Status and conservation of the Sumatran tiger. Carnivore, 1, 97-102.

Burnham, K.P. \& Anderson, D. (1998) Model Selection and Multimodel Inference: A Practical Information-Theoretic Approach, 2nd edition. Springer, New York, USA.

Carbone, C., Coulson, T., Christie, S., Conforti, K., Seidensticker, J., Franklin, N. et al. (2001) The use of photographic rates to estimate densities of tigers and other cryptic mammals. Animal Conservation, 4, 75-79.

Carbone, C. \& Gittleman, J.L. (2002) A common rule for the scaling of carnivore density. Science, 295, 2273-2276. 
Carbone, C., Mace, G.M., Roberts, S.C. \& Macdonald, D.W. (1999) Energetic constraints on the diet of terrestrial carnivores. Nature, 402, 286-288.

EfFord, M. (2004) Density estimation in live-trapping studies. Oikos, 106, 598-610.

EFFord, M. (2010) DENSITY 4.4: Spatially Explicit Capture-recapture Zoology Department University of Otago, Dunedin, New Zealand.

Efford, M.G., Dawson, D.K. \& Robiins, C.S. (2004) DENSITY: software for analysing capture-recapture data from passive detector arrays. Animal Biodiversity and Conservation, 27, 217-228.

Franklin, N., Bastoni, Sriyanto, Siswomartono, D., Manansang, J. \& Tilson, R. (1999) Last of the Indonesian tigers: a cause for optimism. In Riding the Tiger: Tiger Conservation in Human-dominated Landscapes (eds J. Seidensticker, S. Christie \& P. Jackson), pp. 130-147. Cambridge University Press, Cambridge, UK.

Gaveau, D.L.A., Epting, J., Lyne, O., Linkie, M., Kumara, I. \& Kanninen, M. (2009) Evaluating whether protected areas reduce tropical deforestation in Sumatra. Journal of Biogeography, $36,2165-2175$.

Gerber, B.D., Karpanty, S.M. \& Kelly, M.J. (2012) Evaluating the potential biases in carnivore capture-recapture studies associated with the use of lure and varying density estimation techniques using photographic-sampling data of the Malagasy civet. Population Ecology, 54, 43-54.

Global Tiger Recovery Program (2010) Global Tiger Recovery Program: Executive Volume. Global Tiger Initiative. Http://www. globaltigerinitiative.org [accessed 7 November 2012].

Griffiths, M. (1994) Population density of Sumatran tigers in Gunung Leuser National Park. In Sumatran Tiger Report: Population and Habitat Viability Analysis (eds R. Tilson, K. Sumarna, W. Ramono, S. Lusli, K. Traylor-Holzer \& U.S. Seal), pp. 93-102. Indonesian Directorate of Forest Protection and Nature Conservation, and IUCN/SSC Conservation Breeding Specialist Group, Apple Valley, Minnesota, USA.

Griffiths, M. \& VAN SCHAik, C.P. (1993) The impact of human traffic on the abundance and activity periods of Sumatran rain forest wildlife. Conservation Biology, 7, 623-626.

Harihar, A., Pandav, B. \& Goyal, S.P. (2009) Responses of tigers (Panthera tigris) and their prey to removal of anthropogenic influences in Rajaji National Park, India. European Journal of Wildlife Research, 55, 97-105.

IUCN (2001) IUCN Red List Categories and Criteria v. 3.1. IUCN, Gland, Switzerland. Http://www.iucnredlist.org/static/ categories_criteria_3_1 [accessed 7 November 2012].

Karanth, K.U. (1995) Estimating tiger Panthera tigris populations from camera-trap data using capture recapture models. Biological Conservation, 71, 333-338.

Karanth, K.U., Kumar, N.S. \& Nichols, J.D. (2002) Field surveys: estimating absolute densities of tigers using capture-recapture sampling. In Monitoring Tigers and Their Prey: A Manual for Researchers, Managers and Conservationists in Tropical Asia (eds K.U. Karanth \& J.D. Nichols), pp. 139-152. Centre for Wildlife Studies, Bangalore, India.

KaRAnth, K.U. \& Nich OLS, J.D. (1998) Estimation of tiger densities in India using photographic captures and recaptures. Ecology, 79, 2852-2862.

Karanth, K.U. \& Nichols, J.D. (2002) Monitoring tiger populations: why use capture-recapture sampling? In Monitoring Tigers and Their Prey: A Manual for Researchers, Managers and Conservationists in Tropical Asia (eds K.U. Karanth \& J.D. Nichols), pp. 153-166. Centre for Wildlife Studies, Bangalore, India.
Karanth, K.U., Nichols, J.D., Kumar, N.S. \& Hines, J.E. (2006) Assessing tiger population dynamics using photographic capturerecapture sampling. Ecology, 87, 2925-2937.

Karanth, K.U., Nichols, J.D., Kumar, N.S., Link, W.A. \& Hines, J.E. (2004) Tigers and their prey: predicting carnivore densities from prey abundance. Proceedings of the National Academy of Sciences of the USA, 101, 4854-4858.

Karanth, K.U. \& Smith, B.M. (1999) Prey depletion as a critical determinant of tiger population viability. In Riding the Tiger: Tiger Conservation in Human-dominated Landscapes (eds J. Seidensticker, S. Christie \& P. Jackson), pp. 100-113. Cambridge University Press, Cambridge, UK.

Karanth, K.U. \& Sunquist, M.E. (1995) Prey selection by tiger, leopard and dhole in tropical forests. Journal of Animal Ecology, 64, 439-450.

KaWAnishi, K. \& Sunquist, M. (2004) Conservation status of tigers in a primary rainforest of Peninsular Malaysia. Biological Conservation, 120, 329-344.

Krausman, P.R. (2002) Introduction to Wildlife Management. Prentice Hall International, London, UK.

Laumonier, Y. (1997) The Vegetation and Physiography of Sumatra. Kluwer Academic Publishers, Dordrecht, The Netherlands.

Linkie, M., Chapron, G., Martyr, D.J., Holden, J. \& LeaderWilliams, N. (2006) Assessing the viability of tiger subpopulations in a fragmented landscape. Journal of Applied Ecology, 43, 576-586.

Linkie, M., Haidir, I.A., Nugroho, A. \& Dinata, Y. (2008a) Conserving tigers Panthera tigris in selectively logged Sumatran forests. Biological Conservation, 141, 2410-2315.

Linkie, M., Wibisono, H.T., Martyr, D.J. \& Sunarto (2008b) Panthera tigris ssp. sumatrae. In IUCN Red List of Threatened Species v. 2012.2. Http://www.iucnredlist.org [accessed 15 January 2013].

Maddox, T., Priatna, D., Gemita, E. \& Salampessy, A. (2007) The Conservation of Tigers and Other Wildife in Oil Palm Plantations. ZSL Conservation Report No. 7, Zoological Society of London, London, UK.

Morell, V. (2007) Can the wild tiger survive? Science, 317, 1312-1314. NG, J. \& Nemora (2007) Tiger Trade Revisited in Sumatra, Indonesia. TRAFFIC, Petaling Jaya, Malaysia.

Nichols, J.D. \& Karanth, K.U. (2002) Statistical concepts: estimating absolute densities of tigers using capture-recapture sampling. In Monitoring Tigers and their Prey: A Manual for Researchers, Managers and Conservationists in Tropical Asia (eds K.U. Karanth \& J.D. Nichols), pp. 121-137. Centre for Wildlife Studies, Bangalore, India.

Nowell, K. \& Jackson, P. (1996) Status Survey and Conservation Action Plan: Wild Cats. IUCN/Species Survival Commission Cat Specialist Group, IUCN, Gland, Switzerland.

O’Brien, T.G., Kinnaird, M.F. \& Wibisono, H.T. (2003) Crouching tigers, hidden prey: Sumatran tiger and prey populations in a tropical forest landscape. Animal Conservation, 6, 131-139.

Obbard, M.E., Howe, E.J. \& Kyle, C.J. (2010) Empirical comparison of density estimators for large carnivores. Journal of Applied Ecology, $47,76-84$.

Otis, D.L., Burnham, K.P., White, G.C. \& Anderson, D.R. (1978) Statistical inference from capture data on closed animal populations. Wildlife Monograph, 62, 5-44.

RaYan, D.M. \& Mohamad, S.W. (2009) The importance of selectively logged forests for tiger Panthera tigris conservation: a population density estimate in Peninsular Malaysia. Oryx, 43, 48-51.

R Development Core Team (2008) R: A Language and Environment for Statistical Computing. R Foundation for Statistical Computing, Vienna, Austria. 
Rexstad, E. \& Burnham, K. (1992) User's Guide for Interactive Program Capture. Colorado State University, Fort Collins, USA.

Sanderson, E., Forrest, J., Loucks, C., Ginsberg, J., Dinerstein, E., Seidensticker, J. et al. (2006) Setting Priorities for the Conservation and Recovery of Wild Tigers: 2005-2015. WCS, WWF, Smithsonian, and NFWF-STF, New York, USA.

Sharma, R.K., Jhala, Y., Qureshi, Q., Vattakaven, J., Gopal, R. \& NAYAK, K. (2010) Evaluating capture-recapture population and density estimation of tigers in a population with known parameters. Animal Conservation, 13, 94-103.

Shepherd, C.R. \& Magnus, N. (2004) Nowhere to Hide, the Trade in Sumatran Tigers. TRAFFIC South-East Asia, Petaling Jaya, Malaysia.

Soehartono, T., Wibisono, H.T., Sunarto, Martyr, D., Susilo, H.D. \& Maddox, T. (2007) Strategi dan Rencana Aksi Konservasi Harimau Sumatera (Panthera tigris sumatrae) 2007-2017. Departemen Kehutanan, Jakarta, Indonesia.

SRIYANTO (2003) Kajian mangsa harimau Sumatera (Panthera tigris sumatrae) di Taman Nasional Way Kambas, Lampung. MSc thesis. Institut Pertanian Bogor, Bogor, Indonesia.

SunARTO (2011) Ecology and restoration of Sumatran tigers in forest and plantation landscapes. $\mathrm{PhD}$ thesis, Virginia Tech, Blacksburg, USA.

Tredick, C.A. \& Vaughan, M.R. (2009) DNA-based population demographics of black bears in coastal North Carolina and Virginia. Journal of Wildlife Management, 73, 1031-1039.

Uryu, Y., Mott, C., Foead, N., Yulianto, K., Budiman, A. \& Setiabudi (2007) Deforestation, Forest Degradation, Biodiversity Loss and $\mathrm{CO}_{2}$ Emissions in Riau, Sumatra, Indonesia. WWF Indonesia, Jakarta, Indonesia.

Uryu, Y., Purastuti, E., Laumonier, Y., Sunarto, Setiabudi \& Budiman, A. (2010) Sumatra's Forests, their Wildlife and the Climate. Windows in Time: 1985, 1990, 2000 and 2009. A quantitative assessment of some of Sumatra's natural resources submitted as technical report by invitation to the National Forestry
Council (DKN) of Indonesia. WWF Indonesia, Jakarta, Indonesia.

Walston, J., Robinson, J.G., Bennett, E.L., Breitenmoser, U., Da Fonseca, G.A.B., Goodrich, J. et al. (2010) Bringing the tiger back from the brink-the six percent solution. PLoS Biology, $8,1-4$.

Whitten, T., Damanik, S.J., Anwar, J. \& Hisyam, N. (2000) The Ecology of Sumatra. The Ecology of Sumatra Series, Vol. 1, Periplus, Singapore.

Wibisono, H.T., Figel, J.J., Arif, S.M., Ario, A. \& Lubis, A.H. (2009) Assessing the Sumatran tiger (Panthera tigris sumatrae) population in Batang Gadis National Park, a new protected area in Indonesia. Oryx, 43, 634-638.

Wibisono, H.T. \& Pusparini, W. (2010) Sumatran tiger (Panthera tigris sumatrae): a review of conservation status. Integrative Zoology, 5, 309-318.

Wikramanayake, E., Dinerstein, E., Seidensticker, J., Lumpkin, S., Pandav, B., Shrestha, M. et al. (2011) A landscapebased conservation strategy to double the wild tiger population. Conservation Letters, 4, 219-227.

\section{Biographical sketches}

SUNARTO has research interests in the ecology and conservation of threatened wildlife, and is investigating the ecology of tigers in the matrix of forests and plantations in Sumatra. MARCELla J. Kelly carries out research on the conservation of large carnivores using non-invasive techniques. SyBILLE KLENZENDORF's research interest is the conservation of large carnivores. MICHAEL R. VAUGHAN is interested in the ecology and management of large carnivores, including the American black bear. Zulfahmi has been part of the WWF tiger research team for more than 5 years. M.B. HutAJULU is a forest ranger working for Tesso Nilo National Park, with research interests in the management of wildlife. KARMILA PARAKKASI's research interest is the use of habitat corridors by tigers. 